\title{
Fusion of Medical Images in Wavelet Domain: A Discrete Mathematical Model
}

\author{
Fusión de imágenes médicas en el ámbito de la \\ transformada de ondícula: modelo matemático discreto
}

\author{
Satya Prakash $\operatorname{Yadav}^{1} \bowtie$, Sachin $\operatorname{Yadav}^{2}$ \\ ${ }^{1}$ IEC Group of Institutions, Greater Noida, India \\ ${ }^{2}$ Department of Computer Science and Engineering, G.L. Bajaj Institute of technology and \\ Management (GLBITM),
}

Plot No.: -4, Knowledge Park-1, Institutional Area, Surajpur Kasna Road, Greater Noida, India. Email: satyayadav.cs@ ieccollege.com

Received on: October $21^{\text {th }}, 2017 \quad$ Accepted on: February $13^{\text {th }}, 2018 \quad$ Available online: May $1^{\text {st }}, 2018$
How to cite this article: S.P. Yadav and S.Yadav. "Fusion of Medical Images in Wavelet Domain: A Discrete Mathematical
Model", Ing. Sol., vol. 14, no. 25 (Special issue), pp. 11, May, 2018. doi: https://doi.org/10.16925/.v14i0.2236

\begin{abstract}
Introduction: Image compression is a great instance for operations in the medical domain that leads to better understanding and implementations of treatment, especially in radiology. Discrete wavelet transform (DWT) is used for better and faster implementation of this kind of image fusion.

Methodology: To access the great feature of mathematical implementations in the medical domain we use wavelet transform with DWT for image fusion and extraction of features through images.

Results: The predicted or expected outcome must help better understanding of any kind of image resolutions and try to compress or fuse the images to decrease the size but not the pixel quality of the image.

Conclusions: Implementation of the Dwt mathematical approach will help researchers or practitioners in the medical domain to attain better implementation of the image fusion and data transmission, which leads to better treatment procedures and also decreases the data transfer rate as the size will be decreased and data loss will also be manageable.

Originality: The idea of using images may decrease the size of the image, which may be useful for reducing bandwidth while transmitting the images. But the thing here is to maintain the same quality while transmitting data and also while compressing the images.

Limitations: As this is a new implementation, if we have committed any mistakes in image compression of medical-related information, this may lead to treatment faults for the patient. Image quality must not be reduced with this implementation.
\end{abstract}

Keywords: discrete wavelet transform, image fusion, scaling function, wavelet function. 


\title{
Fusión de imágenes médicas en el ámbito de la transformada de ondícula: modelo matemático discreto
}

\author{
Resumen \\ Introducción: la compresión de imágenes es una gran instancia para las operaciones en el ámbito médico que \\ conduce a una mejor comprensión e implementación del tratamiento, especialmente en radiología. La transfor- \\ mada de ondícula discreta (DWT) se utiliza para lograr una mejor y más rápida implementación de este tipo de \\ fusión de imágenes.
}

Metodología: para aprovechar los grandes beneficios de las implementaciones matemáticas en el ámbito médico, empleamos la transformada de ondícula con owt para la fusión de imágenes y extracción de características mediante imágenes.

Resultados: el resultado previsto o esperado es ser capaces de comprender mejor cualquier tipo de resolución de imagen e intentar comprimir o fusionar las imágenes para reducir su tamaño, pero no la calidad de píxel de la imagen.

Conclusiones: la implementación del enfoque matemático dwr ayudará a investigadores o profesionales en el campo médico a lograr una mejor implementación de la fusión de imágenes y transmisión de datos, lo que conduce a mejores procedimientos en el tratamiento y también a disminuir el índice de transferencia de datos debido a la reducción en el tamaño de las imágenes; la pérdida de datos también se vuelve más manejable.

Originalidad: la idea de fusionar las imágenes puede disminuir el tamaño de las mismas, lo cual sería útil para reducir el ancho de banda necesario para su transmisión. Lo que resulta crucial es poder mantener la misma calidad mientras se transmiten los datos y mientras se comprimen las imágenes.

Limitaciones: como se trata de una nueva implementación, si se ha cometido algún error en la compresión de la imagen de información médica, esto puede conducir a fallas en el tratamiento de un paciente. La calidad de la imagen no debe reducirse con esta implementación.

Palabras clave: transformada de ondícula discreta, fusión de imagen, función de escalas, función transformada de ondícula.

\section{Fusão de imagens médicas no âmbito da transformada de wavelet: modelo matemático discreto}

\section{Resumo}

Introdução: a compreensão de imagens é uma grande instância para as operações no âmbito médico e conduz a uma melhor compreensão e implantação do tratamento, especialmente em radiologia. A transformada discreta de wavelet (DWT) é utilizada para obter uma implantação melhor e mais ágil desse tipo de fusão de imagens.

Métodos: para aproveitar os grandes benefícios das implantações matemáticas no âmbito médico, empregamos a transformada discreta de wavelet (DwT) para a fusão de imagens e obtenção de características a partir de imagens.

Resultados: o resultado previsto ou esperado é que seja possível compreender melhor qualquer tipo de resolução de imagem e tentar comprimir ou fusionar as imagens para reduzir o tamanho delas, mas não a qualidade de pixel da imagem.

Conclusões: a implantação do enfoque matemático owt ajudará os pesquisadores ou profissionais no campo médico a obterem uma melhor implantação da fusão de imagens e da transmissão de dados, o que conduz a melhores procedimentos de tratamento e também a diminuir o índice de transferência de dados que, devido à redução no tamanho das imagens e à perda de dados, também se torna mais maleável.

Originalidade: a ideia de juntar as imagens pode diminuir o tamanho delas, o que pode ser útil para reduzir a largura da banda que é necessária para a sua transmissão. 0 que resulta crucial é poder manter a mesma qualidade enquanto os dados são transmitidos e as imagens são comprimidas.

Limitações: como se trata de uma nova implantação, se for cometido algum erro na compreensão da imagem de informação médica, isso poderá levar a falhas no tratamento de um paciente. A qualidade da imagem não deve ser reduzida com essa implantação.

Palavras-chave: função de escalas, função transformada de wavelet, fusão de imagem, transformada discreta de wavelet. 


\section{Introduction}

A discrete wavelet transform is a mathematical tool used to extract and represent the local property as well as features at different modes with great relevance to the image. The band pass (low pass and high pass) represents the special characteristics of the discrete wavelet transform, which decomposes the volume of images to retrieve the frequency and determine which image will be suitable to combine or which image has to be removed from the fused volume coefficient image. The wavelet localizes the waves, having finite energy to decompose the time information in the signal and distribute it throughout the frequency domain [1]-[3]. There are two approaches used to fetch time and frequency information. The first one is Fourier transform that uses only sine and cosine waves in the time domain on the time-frequency plane. The second one is DWT; which is used to decompose the signal with low frequency placing each level of pixels in a coarser resolution [4], [5]. Since the signal information with respect to frequency and time cannot be known at a certain point in the time-frequency plane, this invention goes by the name of "DWT" [6]-[8]. The DWT decomposes the original image into four sub-images of $1 / 4$ of its original size each [9], [10] (Fig. 1).

These sub-images have the details of vertical, horizontal and diagonal components to perform on the row and then columns for retrieving two types of results that have three high-frequency bands ( $\mathrm{LH}$, $\mathrm{HL}, \mathrm{HH}$ ) which extract the edges, and one low-frequency band (LL) which does the approximation. The next level of decomposition will again re-divide one target at low-frequency components (LL) with the same $1 / 4$ size, but this next level of decomposition can be performed by using one of the LL, $\mathrm{LH}, \mathrm{HL}$ and $\mathrm{HH}$ bands [11-12]. Functionally this decomposition can be represented as follows:

\section{Literature Review}

Lets consider a few recent works on this kind of research like image fusion technique, which is a mathematical approach. We have few authors who deal with this kind of approach; lets take a wide look at them:

Hong Zherg [1] describes a detailed study on the image fusion technique with wavelet transform technique that considers few images of the same kind and tries to segment the image into several parts and identify the pixel range of the image. Based on the required quality, we can merge the images and also fuse the present images and compress them for better implementation or transfer.

Smt. Mamatha [2] describes image fusion using wavelet transform and curvelet transform to identify the images' resolutions which are not in the straight plain in the plotting vector, so that we may miss some of the measurements in the images in the curved format.

R. K. Sharma [3] describes the procedure of multi-sensor fusion of the image. With it, it's possible to get dimensions from multi-dimension planes, which we can use to identify the images with 3D technology and also with advanced pixel quality. Images like MRI and CT require this kind of approach.

S. Kor [5] describes feature level fusion of the images that maybe useful to identify the feature selection in the images based on the requirement of the images and the measurements from the list of images. Consider MRI as the base requirement, the brain portion would be the sub requirement, then feature selection is required when the main required measurements are identified in the film or image.

Additional to these papers, we studied research works about the wavelet transform that may help to perform better image fusion with

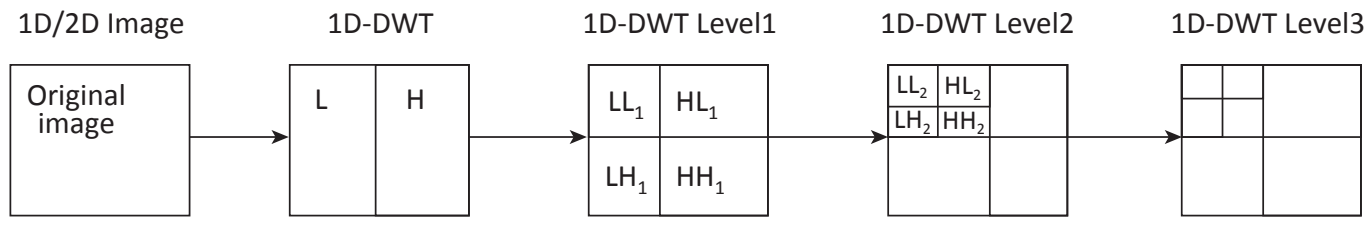

Fig . 1. Image representation of sub band coding

Reference: the authors 


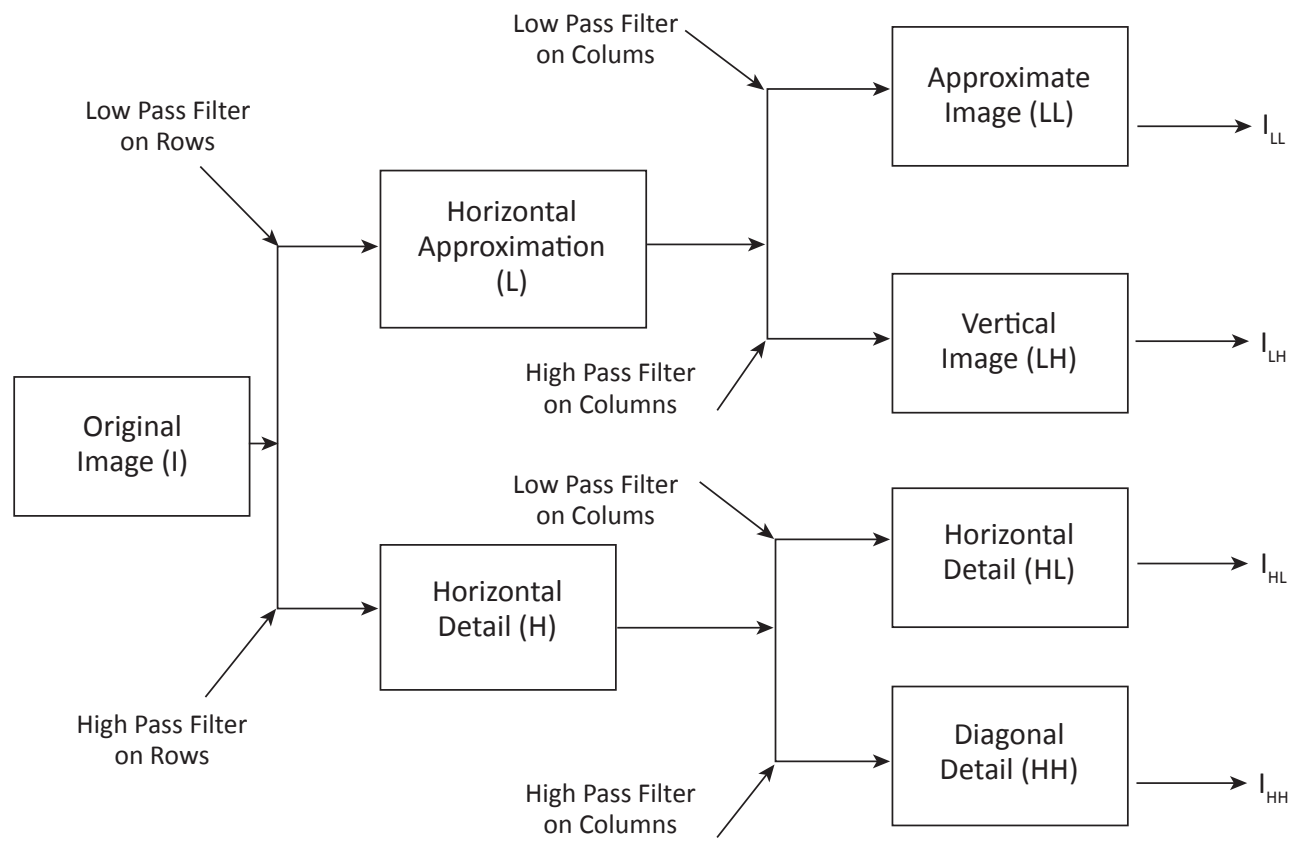

Fig . 2. Functional and sub band representation of a multi resolution scheme at different DWT levels

Reference: the authors

different mathematical forms and identify the features we require in the multi dimensional plane of the workspace.

Kanisetty Venkata Swathi et al. [12] projected a fusion technique for describing the multiple view of a scene through Daubechie's wavelet transform to find the image match coefficients. This fusion practice initiated with the evaluation of coefficient values through frame standard deviation. Characterization of the local variations is used within the block for standard deviation.

J. Srikanth et al. [13] has mentioned the method to achieve the fused wavelet coefficients as output images after using wavelet transforms on the input images. Better information can be obtained using the development of the input image fulfilled by fused images as magnetic resonance imaging (MRI) and Computed Tomography (CT) offered to the doctor and medical action preparation system. Multi-modality wavelet transformation is the technique used to fuse medical images. This research is specially focused on the uses of wavelet transformation and their algorithms on CT and MRI medical images. Fusion can be presented to anticipate the basis of mean quadrangle error.
Ch. Bhanusree et al. [14], study the second-generation wavelet transformation for image fusion and investigate characteristics of the coefficients at different frequency domains. Low frequency coefficients are usually used in local area to select the measuring criteria whereas high frequency coefficients are used for window property and observe the characteristics of the image's local pixels. The practical aspect of this research work is to balance the images using the multi-focus image fusion technique. The system $\mathrm{C}$ language uses the pixel level fusion algorithm to evaluate the result of color images on Xilinx Spartan 3 EDK FPGAstandard.

Kanaka Raju Penmetsa et al. [15], projected a Dual-Tree Complex Wavelet Transform method that de-noises the color images. The complex discrete wavelet transform (CDWT) is the only technique that executed the real and imaginary part of the images; it derives from the discrete wavelet transform (DWT). A result with respect to visual eminence was obtained from color image fusion using the DWT method but DT-CWT is the method that resolved this problem and produced better results than DWT. 
Patil Gaurav Jaywantrao et al. [16] proposed Dual Tree Complex Wavelet Transform (DTCWT) method; which directionally discerns to fuse the image and another one that is shift-invariant and deals with a discrete equivalent of a time-invariant system. The successful fusion technique with several modalities or instruments is worth for medical imaging, remote sensing, industrial use, video surveillance and defense. Now a day fusion of 2D and $3 \mathrm{D}$ images is widely used in the field to traverse the system, Synthetic Aperture Radar (sAR), etc. Therefore the algorithm for $2 \mathrm{D}$ and $3 \mathrm{D}$ images is required. The vital factor for these $2 \mathrm{D}$ and $3 \mathrm{D}$ images is time because the execution of real time fusion system was applied to experiments of multi-focal point images. The proposed research work is to develop the algorithm that uses time as a comparison factor to evaluate the result with respect to what was previously executed.

C. Pavithra et al. [17] projected multi dimensional features with multi focal image resolution with their wavelet transformation to achieve adequate gradient and smoothness criterion. There are several techniques available such as multi- focal point images, multi-sensor satellite images to obtain the fused information of the human brain. Ст and MR images are most widely used to retrieve opposite information from fusion of multi-modal medical images. Wavelet transform is now compared with some of the most used fusion techniques with respect to qualitative and quantitative parameters. After experimental analysis of all fusion techniques including the proposed method, the better result is obtained with wavelet transform that is the proposed method. It is a mathematical aspect of image fusion that simultaneously covered with gradient the areas of uniform intensity and also summed the fused image to minimize the noise. It is not a domain dependent technique.

\section{Methodology}

The source (original) image can be split into four equal parts and result in: ImageLL, ImagelH, ImageHL, and Imageнн [1]. Since the image quadrant contains all the pixels having maximum information, and are very rich in the low frequency [13], [14], therefore in general, image sub-band will lead to more decomposition:

At the first level of decomposition four subbands are used, these are: ImageLL, ImageLH, ImagenL, and Imageнн. In the second level of decomposition, seven sub-bands are used, out of which four sub-band correspond to level two (Imagell will further be divided into Imagell2, ImagelH2, ImageнL2 and Imageнн2), and three sub-bands correspond to level one (ImagelH, ImagenL, and Imageнн). Mathematically, the representation for level two decomposition will be the source (original) image split into four equal parts: ImagelL, ImageLH, ImageHL, and ImageнH. Since image quadrant contains all the pixels having maximum information and are very rich in the low frequency [13], [14], therefore in general, image sub-band will take to further decomposition such as:

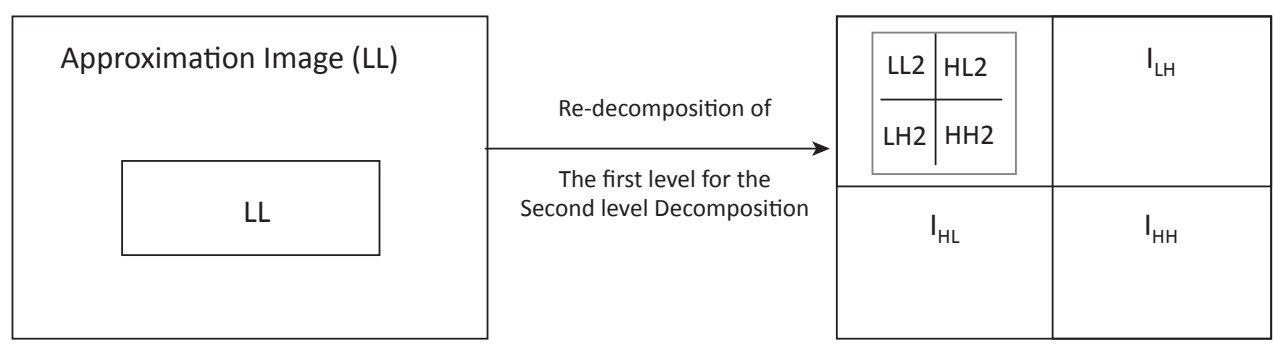

First output image Second output image

Fig . 3. Representation of the image at different decomposition levels Reference: the authors 


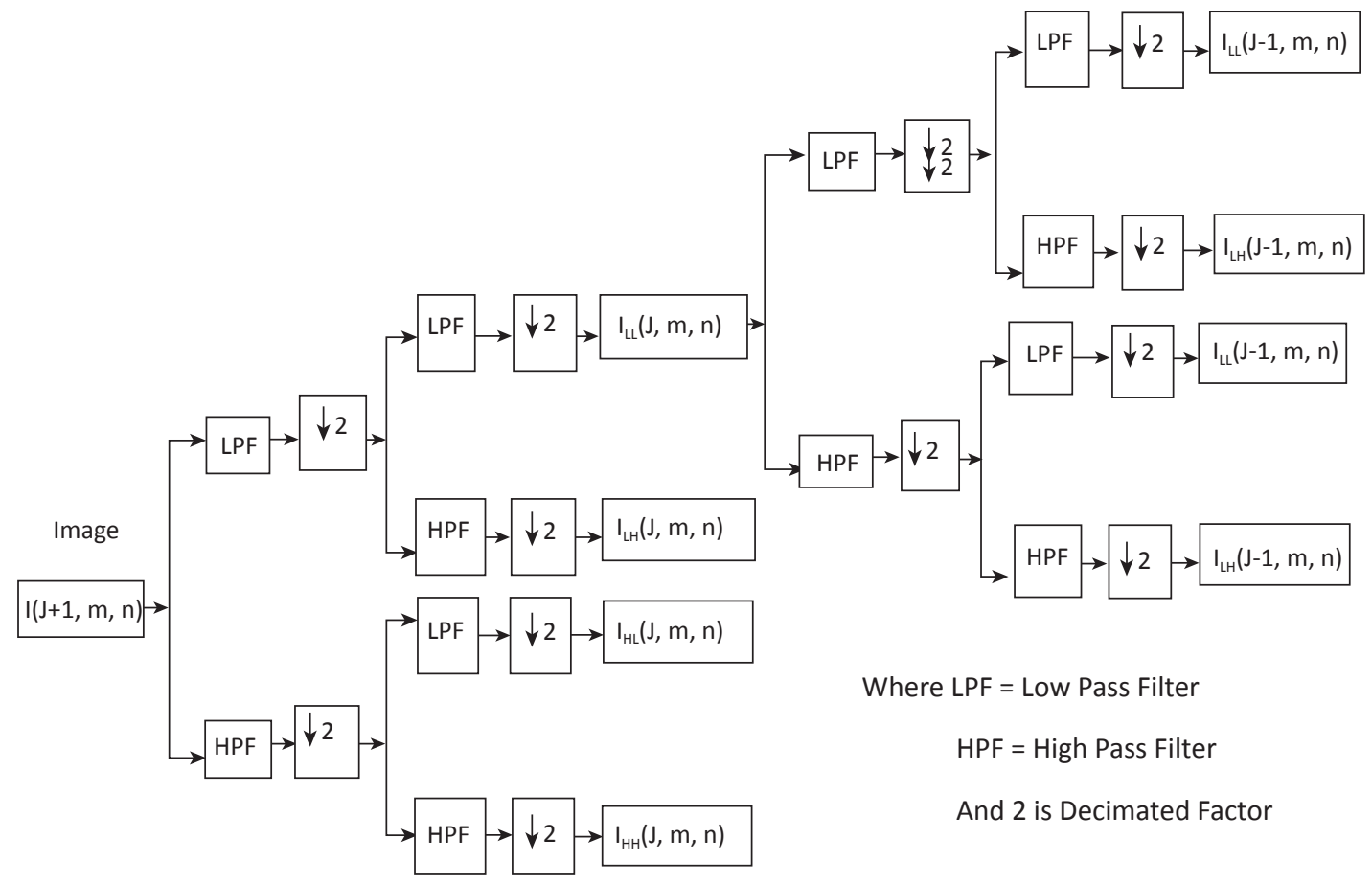

Fig . 4. Image of decomposition at different levels Reference: the authors

Similarly, we will get a redundant sample because according to the Nyquist criteria, we will not lose any information even if we remove half of the signal from the original signal.

\section{Results}

\subsection{The DWT Basis}

DWT is a rapidly growing technique used in several areas such as medicine for diseases diagnosis, artificial intelligence for forecasting and robotics, etc. It is used to enhance the image quality and reduce the computation processing time. It will also be used to extract the characteristics and features from the input image into the output image. The discrete wavelet transform uses two orthogonal functions. These are:

\subsubsection{The Scaling Function}

The scaling function is used for space localization to cover the low frequency to approximate an image at a different level. The scaling function is actually an expansion function by which we can predict exactly where spatial frequency exists. The filter coefficients are generally determined by the scaling function or scaling filter, here both the scaling function and the scaling filter are equivalent. The resulting equation of the scaling function will be as follows:

$$
\emptyset_{j, k}(\mathrm{n})=2^{j / 2} \emptyset\left(2^{j} n-k\right)
$$

Where:

$\left\{\varnothing_{j, k}(\mathrm{n})\right\}=$ Scaling function

$\mathrm{j}=$ Scaling parameter

$\mathrm{k}=$ Shift parameter

$\mathrm{n}=$ Discrete function argument ( $\mathrm{x}$-axis)

$2^{\mathrm{j} / 2}=$ Amplitude / Magnitude of scaling function (y-axis)

$\mathrm{j}, \mathrm{k} \in Z$ (Set of integers space) 


\begin{tabular}{l|l} 
Let put $\mathrm{j}=0, \mathrm{k}=0$ & again put $\mathrm{j}=1, \mathrm{k}=0$ \\
$\emptyset_{0,0}(n)=2^{0} / 2 \emptyset\left(2^{0} n-0\right)$ & $\emptyset_{1,0}(n)=2^{1 / 2} \emptyset\left(2^{1} n-0\right)$ \\
$\emptyset_{0,0}(n)=1 \emptyset(n)$ & $\emptyset_{1,0}(n)=2^{1 / 2} \emptyset\left(2^{1} n-0\right)$ \\
$\emptyset_{0,0}(n)=1 \emptyset(n)$ & $\emptyset_{1,0}(n)=\sqrt{2} \emptyset\left(2^{1} n-0\right)$ \\
Since $\mathrm{n}=0$ and $\emptyset_{0,0}(n)=1$ & Since $\mathrm{n}=1 / 2$ and $\emptyset_{1,0}(n)=\sqrt{2}=1.414$ \\
Since amplitude will be 1 and 0.5 & Then amplitude will be 1.414 with width 0.5 \\
for positive with I for negative. &
\end{tabular}

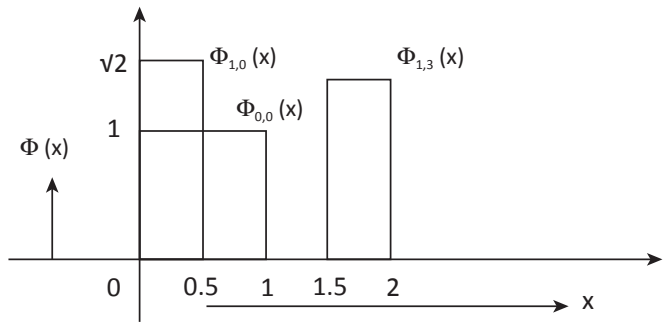

Fig . 5. Frequency signal diagram of scaling function Reference: the authors

The general scaling function for higher shifted versions will be added together as $\Phi_{0,0}(\mathrm{n}), \Phi_{1,0}(\mathrm{n})$, $\Phi_{0,1}(\mathrm{n})$ etc. and can be written as:

$$
\Phi(\mathrm{n})=\sum_{\mathrm{k}} \mathrm{h}_{\Phi}(\mathrm{k}) \cdot \sqrt{2} \cdot \Phi(2 \mathrm{n}-\mathrm{k})
$$

Where:

$\Phi(\mathrm{n})=$ Scaling function

$\mathrm{n}=\mathrm{It}$ is discrete variable

$\Phi(2 \mathrm{n}-\mathrm{k})=$ Higher order function

$\mathrm{h}_{\Phi}(\mathrm{k})=$ Some coefficient which can be obtained by $\Phi_{j, k}(n)$ like $\Phi_{0,0}(n), \Phi_{1,0}(n), \Phi_{0,1}(n)$ etc.

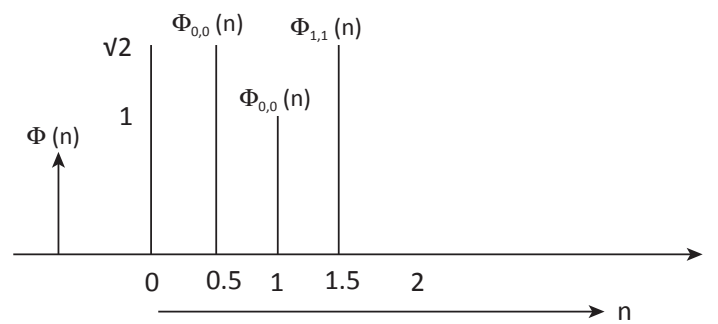

Fig . 6. Frequency signal diagram of the discrete scaling function

Reference: the authors
In a similar way we can obtain the Discrete Scaled function $\omega_{\phi}(j, k)$, that can be written as:

$$
\omega_{\phi}(j, k)=\sum_{m} h_{\varnothing}(m-2 k) \omega_{\phi}(j+1, m)
$$

Thus the scaling function for multi-resolution analysis must have:

- Integer translates of orthogonal

- Sub spaces spanned at low resolution

- A representation with arbitrary precision; the weighted sum of the expansion functions of sub space can be used to express the expansion.

\subsubsection{The Wavelet Function}

Wavelet function is a type of scaling function; which satisfied the requirements for describing the scaling function. The weighted sum of shifted or double resolution can be expressed by the scaling function. This can be represented as:

$$
\Psi_{j, k}(\mathrm{n})=2^{j} / 2 \Psi\left(2^{j} n-k\right)
$$

Where:

$\left\{\Psi_{j, k}(\mathrm{n})\right\}=$ Wavelet function

$\mathrm{j}=$ Wavelet parameter

$\mathrm{k}=$ Shift parameter

$\mathrm{n}=$ Discrete function argument ( $\mathrm{x}$-axis)

$2^{\mathrm{j} / 2}=$ Amplitude / Magnitude of Wavelet function (y-axis)

$\mathrm{j}, \mathrm{k} \in Z$ (Set of integers space)

\begin{tabular}{l|l} 
Let put $\mathrm{j}=0, \mathrm{k}=0$ & again put $\mathrm{j}=1, \mathrm{k}=0$ \\
$\Psi_{0,0}(n)=2^{0} / 2 \Psi\left(2^{0} n-0\right)$ & $\Psi_{1,0}(n)=2^{1 / 2} \Psi\left(2^{1} n-0\right)$ \\
$\Psi_{0,0}(n)=1 \Psi(n)$ & $\Psi_{1,0}(n)=2^{1 / 2} \Psi\left(2^{1} n-0\right)$ \\
$\Psi_{0,0}(n)=1 \Psi(n)$ & $\Psi_{1,0}(n)=\sqrt{2} \Psi\left(2^{1} n-0\right)$ \\
Since $\mathrm{n}=0$ and $\Psi_{0,0}(n)=1$ & Since $\mathrm{n}=1 / 2$ and $\Psi_{1,0}(n)=\sqrt{2}=1.414$ \\
Since amplitude will be 1 and 0.5 & Then amplitude will be 1.414 with width 0.5 \\
for positive with I for negative. &
\end{tabular}




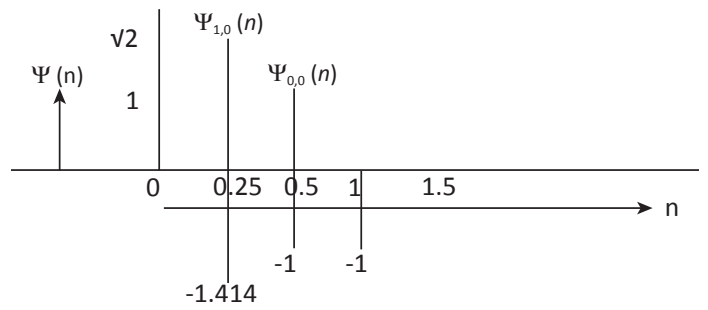

Fig . 7. Frequency signal diagram of the wavelet function Reference: the authors

The general wavelet function for higher shifted versions will be added as $\Psi_{0,0}(n), \Psi_{0,1}(n)$ etc. and can be written as:

$\Psi(\mathrm{n})=\mathrm{a}_{\mathrm{k}}{ }^{\mathrm{h}} \Psi(\mathrm{k})$ and can be

Where:

$\Psi(n)=$ Wavelet function

$\Phi(2 \mathrm{n}-\mathrm{k})=$ Higher order scaling function

$\mathrm{k}=$ Shift parameter

$\mathrm{n}=$ Discrete function argument ( $\mathrm{x}$-axis)

h $\Psi(\mathrm{k})=$ Some coefficient that can be obtained by $\Psi_{j, k}(n)$ like $\Psi_{0,0}(n), \Psi_{1,0}(n)$ etc.

$\mathrm{j}, \mathrm{k} \in \mathrm{Z}=$ Set of integers space

Therefore we can say that $\Psi_{j, k}(n)$ is used to represent the wavelet function where $\Phi_{j, k}(n)$ is used to represent the scale function; which is used to scale the given sub space by a factor of $2^{\mathrm{j} / 2}$. Now it should be possible for us to apply the scaling and wavelet functions in order to filter the image and achieve space frequency localization.

\section{Discussion}

\subsection{The Relation between the Wavelet Function and the Scaling Function}

The most popular method used for image processing such as subband coding, image compression and watermarking are known as Multi-resolution Analysis. The scaling and wavelet function are the two coefficient factors used for calculating the Multi-resolution Analysis. A scaling function translates the integer value at the different level of approximations. The equation (1) is used to calculate the approximation at the nearest neighboring level of the scaling function. Wavelet function is also a kind of scaling function used to calculate the integer coefficient for limited frequency span. The wavelet function uses the equation (4) to calculate the difference between two adjacent subspaces such as V0 and V1, in general it can be written as $\mathrm{Vr}+1=\mathrm{Vr} \oplus \mathrm{Wr}$.

Mathematically it can be calculated as
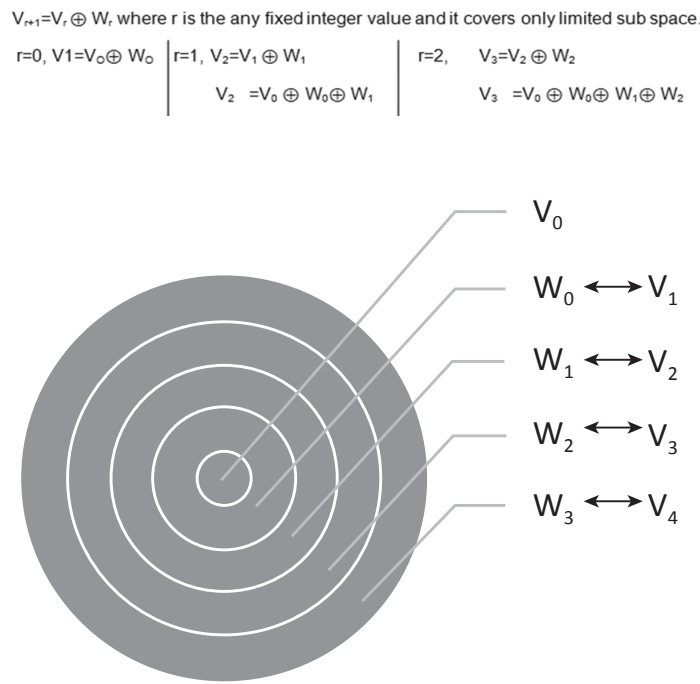

Fig. 8. Spatial relation of scaling and wavelet function spaces Reference: the authors

The spatial scaling function covered by $\Phi_{j, k}(\mathrm{n})$ like $\Phi_{0,0}(\mathrm{n}), \Phi_{1,0}(\mathrm{n}), \Phi_{0,1}(\mathrm{n})$ and $\mathrm{W}_{0}$ will be the difference space of $\mathrm{V} 1=\mathrm{V}_{\mathrm{O}} \oplus \mathrm{W}_{\mathrm{O}}$.

So in general, we can write and represent the sub spaces as:

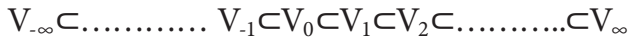

Therefore if the relation of the scaling function is achieved then the corresponding wavelet function will also be obtained [17-18].

\subsection{Discrete Wavelet Transform}

Discrete wavelet transform (DWT) is a method to represent and transform the discrete time signal into a wavelet domain [16]. The discrete wavelet transform is providing efficient multi-resolution based on time scale representation without loss of information. The discrete wavelet transform is 
used in both time and frequency domains to represent the bank of filters localization into high pass frequency and low pass frequency. Low pass frequency contains all the pixels and thus have maximum information and are very rich. This low pass frequency band can be further decomposed until the desired resolution is reached. This is the reason why the discrete wavelet transform has better ability in localization than other transform. It is specially used for signal processing, compression and watermarking without redundant information [11]-[13]. Image compression has two types of losses with a resulting digitally identical representation to the original image and retrieves different amount of compressions, whereas lossy is used to discard components of the signal that are known to be redundant and changed from the input [14], [15]. The discrete wavelet transform uses $S(n)$ as the function with the discrete parameter ' $n$ ' having $n=0,1,2,3, \ldots \ldots . . M-1$ of the signal, where $M$ is considered the total number of samples used in a signal and can be written as:

$$
\begin{aligned}
& s(\mathrm{n})=\frac{1}{\sqrt{m}} \sum_{k} \omega_{\phi}\left(j_{0}, k\right) \phi_{j_{0}, k}(\mathrm{n})+ \\
& \sum_{j=j_{0}}^{\infty} \sum_{\mathrm{k}} \omega_{\Psi}(\mathrm{j}, \mathrm{k}) \Psi_{j, k}(\mathrm{n})
\end{aligned}
$$

Where:

$\frac{1}{\sqrt{m}}=$ Normalizing factor

$k=$ Shifted value that was ' $S$ ' in the continuous wavelet domain

$\omega_{\Phi}\left(j_{0}, k\right)=\omega_{\Phi}$ The coefficients associated with the scaling function $\Phi j_{0} \cdot k$ (n) $\Phi j_{0} \cdot k$

$(\mathrm{n})=$ Set of scaling or shifted scaling function

$\omega_{\Psi}(j, k)=\omega_{\Psi}$ The coefficients associated with the wavelet function $\Psi_{j, k}(\mathrm{n})$

$\Psi_{j, k}(\mathrm{n})=$ Set of wavelet or shifted wavelet function

$\mathrm{j}=\mathrm{j}_{0}$ where $\mathrm{j}_{0}$ is used for a certain fixed value

To compute the coefficients $\omega_{\Phi}\left(j_{0}, k\right)$ and $\omega_{\Psi}$ $(j, k)$ which are associated to the scaling function and wavelet function respectively can be written as:

$$
\omega_{\phi}\left(j_{0}, k\right)=\frac{1}{\sqrt{m}} \sum_{n} s(n) \phi_{j_{0} . k}(\mathrm{n})
$$

and similarly:

$$
\omega_{\Psi}(j, k)=\frac{1}{\sqrt{m}} \sum_{n} s(n) \Psi_{j . k}(\mathrm{n}) \quad, \mathrm{j}>=\mathrm{j}_{0}
$$

$\Psi_{j, k}(\mathrm{n})$ is used to represent the Discrete Wavelet Transform function and will be defined as in equation 4 as:

$$
\Psi_{j, k}(\mathrm{n})=2^{j} / 2 \Psi\left(2^{j} n-k\right)
$$
tion 8

Putting the $\Psi_{j, k}(\mathrm{n})$ that is equation 4 in equa-

$$
\omega_{\Psi}(j, k)=\frac{1}{\sqrt{m}} \sum_{n} s(n) 2^{j} / 2 \Psi\left(2^{j} n-k\right)
$$

With another shift parameter 'p', $\Psi$ (n) will be:

$$
\Psi(\mathrm{n})=\sum_{p} \mathrm{~h} \Psi(\mathrm{p}) \sqrt{2} \phi(2 n-p)
$$

Now let $\mathrm{n}=2^{j} n-k$ after putting this value, equation 10 may be rewritten as

$$
\Psi\left(2^{j} n-k\right)=\sum_{p} \mathrm{~h} \Psi(\mathrm{p}) \sqrt{2} \phi\left(2\left(2^{j} n-k\right)-p\right)
$$

Again let $\mathrm{p}=\mathrm{m}-2 \mathrm{k}$ then $2 \mathrm{k}+\mathrm{p}=\mathrm{m}$, now it can be modified and rewritten as

$\Psi\left(2^{j} n-k\right)=\sum_{m} \mathrm{~h} \Psi(\mathrm{m}-2 \mathrm{k}) \sqrt{2} \phi\left(2^{j+1} n-m\right)$

Now put $\Psi\left(2^{j} n-k\right)$ in equation 9

$\omega_{\Psi}(j, k)=\frac{1}{\sqrt{m}} \sum_{n} s(n) 2^{j / 2}\left[\sum_{m} \mathrm{~h} \Psi(\mathrm{m}-2 \mathrm{k}) \sqrt{2} \phi\left(2^{j+1} n-m\right)\right]$

Now if we swap the order of the sum, we get:

$\left.\omega_{\Psi}(j, k)=\sum_{m} \mathrm{~h} \Psi(\mathrm{m}-2 \mathrm{k}) \frac{1}{\sqrt{m}} \sum_{n} s(n) 2^{(j+1) / 2} \phi\left(2^{j+1} n-m\right)\right]$ 
Where:

$$
\omega_{\phi}(j+1, m)=\frac{1}{\sqrt{m}} \sum_{n} s(n) 2^{(j+1) / 2} \phi\left(2^{j+1} n-m\right)
$$

Then $\omega_{\Psi}(j, k)$ can be rewritten as:

$$
\omega_{\Psi}(j, k)=\sum_{m} \mathrm{~h} \Psi(\mathrm{m}-2 \mathrm{k}) \omega_{\phi}(j+1, m)
$$

DWT is a process of applying localization in both time and frequency to be represented as a bank of filters. Signals split into high frequency and low-frequency components, where low-frequency components can be further decomposed until the desired resolution is reached. Therefore the DWT has a better ability in localization than other transforms [19], [20].

\section{Conclusion}

1. The DWT was useful to provide the complete time and frequency information in a parallel way and to solve the resolution, i.e., if we are decreasing the image resolution, we need to consider the pixel quality as this is a medical image concept.

2. Imaging compression was successful using DWT as the mathematical approach for better segmenting the regions and compress the images with high resolution.

3. Fourier Transform plays a crucial role in image compression and medical image compression. Fourier transforms plays very well in image compression without decreasing the image quality and data lapse.

4. Data fusion is a key methodology for image transforming in a better way without any time or frequency lapse, using DWT and Fourier transform we achieved it so in a great way.

\section{References}

[1] H. Zheng, D. Zheng,Y.Hu, and S. Li, "Study on the Optimal Parameters of Image Fusion Based on Wavelet Transform [J]", Journal of Computational Information Systems, vol. 6, no. 1, pp. 131-137, 2010 [Online]. Available: https://www.researchgate.net/ publication/229041632_Study_on_the_Optimal_ Parameters_of_Image_Fusion_Based_on_Wavelet_ Transform
[2] G. Mamatha and L. Gayatri, "An Image Fusion Using Wavelet And Curvelet Transforms", Global Journal of Advanced Engineering Technologies, vol. 1, no. 2, pp. 69-73, 2012.

[3] R. K. Sharma, "Probabilistic Model-based Multisensor Image Fusion”, PhD thesis, Oregon Graduate Institute of Science and Technology, Portland, Oregon, 1999 [Online]. Available: http://citeseerx.ist.psu. edu/viewdoc/download?doi=10.1.1.35.8418\&re$\mathrm{p}=$ rep $1 \&$ type $=\mathrm{pdf}$

[4] S. Li, J. T. Kwok, and Y. Wang, "Combination of images with diverse focuses using the spatial frequency," Information Fusion, vol. 2, no. 3, pp. 169-176, 2001. DOI: https://doi.org/10.1016/s15662535(01)00038-0

[5] S. Kor and U. Tiwary, "Feature level fusion of multimodal medical images in lifting wavelet transform domain", IEEE International Conference of the Engineering in Medicine and Biology Security, pp. 1479-1482, 2004. doi: https://doi.org/10.1109/ iembs.2004.1403455

[6] A. H. Gunatilaka and B. A. Baertlein, "Feature-level and decision-level fusion of non coincidently sampled sensors for land mine detection", IEEE Transactions on Pattern Analysis and Machine Intelligence, vol. 23, no. 6, pp. 577-589, 2001. doi: https://doi. org/10.1109/34.927459

[7] D. Kaur and P. S. Mann, "Medical Image Fusion Using Gaussian Filter, Wavelet Transform and Curvelet Transform Filtering", International Journal of Engineering Science \& Advanced Technology, vol. 4, no. 3, pp. 252-256, 2015 [Online]. Available: http:// citeseerx.ist.psu.edu/viewdoc/citations;jsessioni$\mathrm{d}=1$ F48D660C40A8F5FD60BC37274178AF7? doi=10.1.1.690.865

[8] M. C. El-Mezouar, N. Taleb, K. Kpalma, and J. Ronsin, "An IHs-Based Fusion for Color Distortion Reduction and Vegetation Enhancement in IKONOs Imagery", IEEE Transactions on Geo-science And Remote Sensing, vol. 49, no. 5, May 2011. doi: https:// doi.org/10.1109/tgrs.2010.2087029

[9] C. K. Solanki and N .M. Patel, "Pixel based and Wavelet based Image fusion Methods with their Comparative Study", National Conference on Recent Trends in Engineering \& Technology, May 13-14, 2011.

[10] R. P. Singh-Chauhan, R. Dwivedi, and S. Negi "Comparative Evaluation of DWT and DT-CWT for Image Fusion and De-noising", International Journal of Applied Information Systems (IJAIS), vol. 4, no. 2, pp. 40-45, September 2012. doi: https://doi. org/10.5120/ijais12-450662

[11] S. Sruthi, L. Prameswara, and A. P, Sasi, "Image Fusion Technique using DT-CWT", in Proceedings 
of IEEE. Kottayam, India, March 22-22, 2013. doi: https://doi.org/10.1109/imac4s.2013.6526400

[12] K. V. Swathi and Ch. H. Bindu, "Modified Approach of Multimodal Medical Image Using Daubechies Wavelet Transform", International Journal of Advanced Research in Computer and Communication Engineering, vol. 2, no. 11, November 2013, pp. 4199-4201.

[13] J. Srikanth and C.N. Sujatha, "Image Fusion Based on Wavelet Transform for Medical Diagnosis", Int. Journal of Engineering Research and Applications, vol. 3, no. 6, pp.252-256, Nov-Dec 2013.

[14] Ch. Bhanusree and P. A. Ratna-Chowdary "A Novel Approach of image fusion MRI and CT image using Wavelet family", International Journal of Application or Innovation in Engineering \& Management (IJAIEM), vol. 2, no. 8, pp. 1-4, August 2013,

[15] K. R. Penmetsa, V. G. Prasad-Naraharisetti, and N. Venkata "RAO An Image Fusion Technique For Color Images Using Dual-Tree Complex Wavelet Transform", International Journal of Engineering Research \& Technology (IJERT), vol. 1, no. 8, October 2012.

[16] P. G. Jaywantrao and S. Hasan, "Application of Image Fusion Using Wavelet Transform In Target Tracking System", International Journal of Engineering Research \& Technology (IJERT), vol. 1, no. 8, pp. 1-6, October 2012.
[17] C. Pavithra and S. Bhargavi, "Fusion of Two Images Based on Wavelet Transform", International Journal of Innovative Research in Science, Engineering and Technology, vol. 2, no. 5, pp. 1814-1819, May 2013.

[18] R. Singh and A. Khare, "Multimodal medical image fusion using daubechies complex wavelet transform", in IEEE Conference on Information \& Communication Technologies (ICT), April 2013, pp. 869-873. doi: https://doi.org/10.1109/cict.2013.6558217

[19] D. R. Bull, C. N. Canagarajah, M. Halliwell, P. N. T. Wells, and S. G. Nikolov, "Image fusion using a 3-D wavelet transform", in Seventh International Conference on Image Processing And Its Applications, vol. 1, July 1999, pp. 235-239. doi: https://doi.org/10.1049/ cp: 19990318

[20] A. Deng, J. Wu, and S. Yang, "An Image Fusion Algorithm Based on Discrete Wavelet Transform and Canny Operator", Advanced Research on Computer Education, Simulation and Modeling Communications in Computer and Information Science, vol. 175, 2011, pp. 32-38. doi: https://doi.org/10.1007/978-3642-21783-8_6 